Naturseide erfolgt bei allen Wellenlängen. Vergilbung. Optisch aufgehellte Wolle verhält sich bei Bestrahlung mit der Wellenlänge $310 \mathrm{~nm}$ wie nicht optisch aufgehellte. War aber mit der Wellenlänge $365 \mathrm{~nm}$ bestrahlt worden, so erfolgt bei der anschließenden Befeuchtung eine viel stärkere Vergilbung. Naturseide verhält sich bei dieser Wellenlänge ähnlich. Der Befund anderer Autoren, daß bei Ausschluß von Sauerstoff keine Vergillbung eintritt, konnte auch bei Anwesenheit von Wasser bestätigt werden. A. Sippel (Freiburg i. Br.)

Makinson, K. R. (Div. of Textile Physics, CSIRO, Ryde, Sydney, Australien). Auswirkungen der schrumpffestmachenden Behandlung mittels $\mathrm{KMnO}_{4}$ und Salz auf das Verhalten von Wollfasern beim Reiben. I. Korrelation zwischen den statischen Reibungskoeffizienten und Messungen an den Innenseiten und Außenseiten der Kräuselungskurve. (Textile Res. J. 39, 710-721, 1969.)
Von Merinowollfasern, die durch eine Behandlung mit $\mathrm{KMnO}_{4}$ and Salz schrumpfbeständig gemacht worden waren, wurde nach der sog. CapstanMethode der ,statische" Reibungskoeffizient bestimmt, wobei die Innenseiten der gekrümmten Stellen von Wollfasern sich bei Anwesenheit einer wäßrigen Flüssigkeit, die entweder Natriumoleat oder ein nichtionisches Detergens enthielt, an einem Hornstäbchen rieben und wobei zwischen der Reibung in Richtung und gegen die Wollfaserschuppen unterschieden wurde. Im wesentlichen wird als Folge der chemischen Behandlung eine starke Zunahme des Reibungskoeffizienten in Schuppenrichtung and je nach Meßbedingungen u. U. eine Abnahme der Differenz der Reibungskoeffizienten in beiden Richtungen festgestellt. Dies wird auf eine Erweichung der Schuppen durch die chemische Behandlung zurückgeführt. Der Einfluß der Meßbedingungen wird ausführlich untersucht. A. Sippel (Freiburg i. Br.)

\title{
Berichtigung zur Arbeit \\ Über die Bestimmung der chemischen Uneinheitlichkeit von Copolymeren mit Hilfe der magnetischen Kernresonanz (NMR)
}

Von K. Unterforsthuber

Kolloid-Z. u. Z. Polymere 238, 430 (1970)

In dieser Arbeit fehlt die Angabe:

Aus dem Deutschen Kunststoff-Institut, Darmstadt

Sonderdrucke können unter folgender Anschrift angefordert werden:

Deutsches Kunststoff-Institut, 61 Darmstadt, Schloßgartenstraße 6 R

\section{Errata to}

\section{Some dielectric properties of dry keratin}

(Kolloid-Zeitschrift und Zeitschrift für Polymere, Band 223, 13 (1968)

and

\section{Some dielectric properties of wool}

(Kolloid-Zeitschrift und Zeitschrift für Polymere, Band 234, 1069 (1969)

$$
\text { By J.E. Algie }
$$

Recent experiments have shown that the so-called "dry" rhinoceros horn for which dielectric data was reported (1), in fact contained $1-2 \%$ of absorbed water in comparison with a sample dried at $140^{\circ} \mathrm{C}$ for $\mathrm{I}$ week under continuous evacuation. The data (1) is therefore not for thoroughly dry keratin and the absorption peak called $\beta$ is in fact due to orientation of the sorbed water itself. The $\beta$ peak in the results obtained for wool at various water contents (2) is also due to orientation of the absorbed water. The major conclusions in ref. (1) are unaffected by the above error but the dielectric properties of vacuum dried keratin have been examined and will be published shortly.

Für die Schriftleitung verantwortlich: Für Originalarbeiten Prof. Dr. F. H. Müller, 3550 Marbach b. Marburg/Lahn und Prof. Dr. A. Weiss, 8000 München 2 für Referate und Berichte Dr. K. Requardt, 6078 Neu-Isenburg

Anzeigenverwaltung: Dr. Karl Niedermeyer Nachf., 6000 Frankfurt/M. 90, Georg-Speyer-Straße 76

Dr. Dietrich Steinkopff Verlag, 6100 Darmstadt, Saalbaustraße 12

Herstellung: Universitätsdruckerei Mainz GmbH 